\title{
Um Diálogo entre um Cristão Ortodoxo e um Behaviorista Radical
}

A dialogue between an orthodox christian and a radical behaviorist

Tyffanne Serra Paraná Rodrigues \& Alexandre Dittrich

Universidade Federal do Paraná 


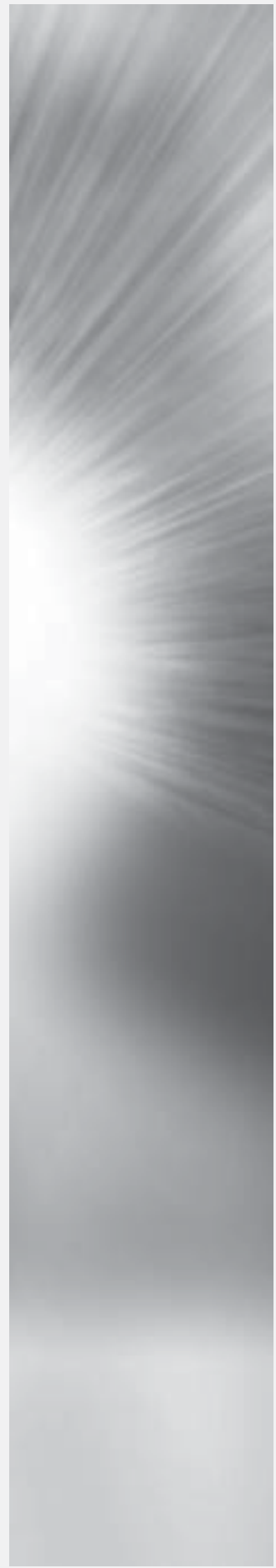

Resumo:Este artigo discute a religião através de um diálogo entre dois sujeitos fictícios: Tommaso, um behaviorista radical e defensor da idéia skinneriana de que a religião não se diferencia de outras formas de controle, e Gottlieb, um cristão ortodoxo e entusiasta da religiosidade. As posições de Tommaso baseiam-se em uma ampla revisão sobre a religião na literatura behaviorista radical, que incluem todos os livros de B. F. Skinner; por sua vez, textos favoráveis à religiosidade, ainda que nem todos mencionem teorias psicológicas, têm Gottlieb como seu portavoz. Além de se constituir em uma análise conceitual abrangente no interior da literatura behaviorista/skinneriana, este trabalho, favorecendose do método dialógico de exposição e, assim, recriando discussões dialéticas nas quais Gottlieb representa o interlocutor oculto nos textos behavioristas, que poderia apresentar argumentos semelhantes aos por ele suscitados, promove novas e distintas reflexões sobre a religiosidade e contribui, portanto, para maior elucidação do tema em questão.

Palavras-chave: religião, behaviorismo radical, Skinner, cristianismo ortodoxo.

Abstract: This article discusses religion by means of a dialogue between two fictitious characters: Tommaso, a radical behaviorist and defender of the skinnerian idea that religion is such a control agency as any other, and Gottlieb, an orthodox christian and a religiosity enthusiast. Tommaso's positions are based on an extensive revision about religion in the radical behaviorist literature, including all B. F. Skinner's books; in turn, texts favorable to religiosity, even if not all of them mention psychological theories, have Gottlieb as their spokesman. Besides being made of a comprehensive conceptual analysis of the behaviorist/skinnerian literature, this work - taking advantage of the dialogical method of exposition and, therefore, recreating dialectical discussions where Gottlieb is the occult interlocutor in the behaviorist texts which could show arguments similar to the ones raised by him - promotes new and distinct reflections about religion, contributing, this way, to a better elucidation of the present subject.

Key words: religion, radical behaviorism, Skinner, orthodox christianity.
"Este há de ser o fruto de todas as ciências: que por meio delas se edifique a fé."

São Boaventura (1218 - 1274)

"A fé religiosa torna-se irrelevante quando os temores de que se alimenta são mitigados, e as esperanças realizadas - cá na Terra."

Burrhus Frederic Skinner (1904 - 1990) 
Em toda a história da humanidade, não há um momento sequer, na linha do tempo, em que se afirme que o homem tenha experimentado uma fase plena de descrença em Deus ou em quaisquer forças consideradas de ordem superior, absoluta e criadora de todo o universo.
Em toda a história da humanidade, não há um momento sequer, na linha do tempo, em que se afirme que o homem tenha experimentado uma fase plena de descrença em Deus ou em quaisquer forças consideradas de ordem superior, absoluta e criadora de todo o universo. Pelo contrário, se há dúvida acerca dessa assertiva, diversos períodos da História, sejam eles de guerra ou de paz, confirmam a presença da religiosidade dos povos: um exemplo diacrônico é a relevância de textos sagrados na origem de conflitos diversos obviamente, muito mais pelos abusos cometidos na interpretação semântica textual, que convenientemente é agregada aos discursos dos interessados, do que pelo ardor religioso.

Entretanto, é possível inferir que a ação e o pensamento humanos foram profundamente modificados desde os tempos primordiais, ao agregar as qualidades de articulação e racionalidade. Poder-se-ia imaginar, portanto, que tais modificações predisporiam a humanidade ao investimento cada vez maior no raciocínio lógico e na ciência e à revisão de sua ligação com as práticas místicas, o que as relegaria ao passado em definitivo. Mas, se ainda, nos dias de hoje, a religiosidade não sucumbiu à primazia da razão, é de se pensar, portanto, que deve haver motivos para uma ligação de tão longa data.

A religiosidade, ainda que subsistindo ao longo da História, não deixou de ser contestada por alguns céticos, que não se conformaram com as respostas dogmáticas para os mistérios da vida natural e resolveram discutir o que parecia indiscutível para o senso comum. Este trabalho dá atenção a um desses homens que resolveram refletir sobre a religiosidade e contestá-la: Burrhus Frederic Skinner.

Assim, a partir de um diálogo, este trabalho discute a religião através das visões distintas apresentadas por dois sujeitos fictícios: Tommaso, defensor do behaviorismo radical e que, portanto, compartilha a visão de Skinner de que a religião não se diferencia de outras formas de controle presentes na sociedade, e Gottlieb, um cristão ortodoxo, ferrenho defensor da religiosidade humana e da existência de Deus.

A escolha do diálogo como método de exposição do assunto fez-se pelo fato de se recriar a discussão dialética originalmente presente nos textos de Skinner, nos quais Gottlieb representa o interlocutor oculto - o leitor que, ao se confrontar pela primeira vez com as idéias de Skinner a respeito da religião, poderia levantar questões bastante parecidas com as levantadas por Gottlieb.

A preferência pela forma dialógica implica diretamente a opção pela não apresentação de uma seção dedicada às conclusões. Tal escolha faz-se acompanhar de dois motivos que expõem a redundância da presença de conclusões ao final do trabalho: o primeiro deles refere-se ao fato de que, diferentemente de um texto não dialogado, em que se faz pertinente a reunião dos principais tópicos desenvolvidos para uma reflexão final sobre eles, o presente trabalho traz as conclusões implícitas no diálogo que o compõe, ao passo que cada fala traz as inferências dos participantes fundadas em suas diversas premissas; o segundo motivo, e de maior preeminência, é a inevitável redução que as visões dos dois personagens teriam de sofrer para se conformarem aos parágrafos conclusivos, o que invalidaria o uso das conversações que, entre outros intentos, objetivou conferir liberdade aos dois personagens para que manifestassem seus argumentos em defesa de suas posições.

Este trabalho tem, portanto, como objetivos: entender a visão do behaviorismo radical sobre a religião, expondo-a a partir das intervenções de Tommaso, salientando seus aspectos primordiais e contrapondo-as às intervenções de Gottlieb, e discutir os motivos pelos quais o homem se apega à religião - ainda que não seja um dos objetivos deste trabalho dar ênfase 
à visão de mundo religiosa - tanto a partir da ótica de um cristão ortodoxo como a partir da ótica de um behaviorista radical.

Tais objetivos justificam-se pelo fato de que entender o porquê da existência da religiosidade auxilia a entender o próprio homem. Religião e homem não podem ser entendidos separadamente, pois a religiosidade acompanha a evolução cultural humana, inclusive todas as suas idiossincrasias. Homem e religião, portanto, estabelecem entre si uma relação de reciprocidade: a religião incita o homem a se comportar de uma determinada maneira e o homem, por sua vez, molda a religião conforme suas características na forma de ser e agir.

Estudar a forma como uma religião se constitui, os laços que ela estabelece com outras áreas da vida humana - sociopolíticas, por exemplo - é tarefa muito mais da Antropologia do que da Psicologia. A Psicologia quer entender porque o homem se comporta de certa forma, e não de outra qualquer. Para esse fim, portanto, minuciosas descrições das religiões do mundo, além de constituírem um trabalho extremamente árduo em razão das inúmeras versões que as crenças religiosas podem assumir, tornam-se redundantes, apesar de bastante ilustrativas.

Se o objetivo é entender a essência da religião, o porquê no lugar do como, somente um estudo aprofundado sobre o homem, enquanto ser atuante e criador dos sistemas religiosos, é que poderá trazer alguma clareza para esse entendimento.

\section{O diálogo}

Tommaso, um behaviorista radical que não aceita o argumento de que o homem é um ser religioso em sua essência sem tê-lo aprendido, e Gottlieb, um cristão ortodoxo que baseia sua visão de mundo a partir das premissas cristãs, conversam a respeito do motivo pelo qual o homem se submete à religião e acerca da beatitude e das vicissitudes inerentes a essa submissão:

GotTlieb: Quando entro em templos e vejo os fiéis rezando incessantemente, ou quando vejo uma catástrofe e os sobreviventes agradecerem aos céus por estarem vivos, mesmo após terem presenciado seus parentes morrerem de forma brutal e suas casas destroçadas, eu me pergunto: 'Quais as misteriosas contingências presentes nesses momentos? O que reforça o ato de rezar e de crer em Deus em momentos em que nada mais importa, nem mesmo o reforço final de ir para o Paraíso?' Somente o entendimento de que a religião é absoluta e de que o amor a Deus preexiste ao homem traz luz para esses casos excepcionais de fé que sua restrita visão não consegue mais explicar.

TOMmaso: Se compreendermos a religião imprecisamente, sem darmos a devida atenção ao que acontece em cada um desses atos de 'rezar' e de 'agradecer', tendemos a explicála, seja por limitação intelectual ou comodidade, seja pela presença do amor divino absoluto e preexistente a todas as coisas. Mas partamos para o que você mencionou primeiramente: 'fiéis rezando incessantemente'. Rezar é um comportamento e, como tal, não posso concebê-lo sem tentar explicar as razões de suas origens. Se pudéssemos observar a história de vida de cada um desses fiéis, entenderíamos que, ao longo de suas vidas, o comportamento de rezar foi aprendido. De alguma forma, o comportamento de rezar foi seguido por reforçadores consistentes o bastante para mantê-lo por muitos anos. Esse reforçamento já explica, em parte, as 'misteriosas contingências' a que você se refere, mesmo que tais contingências pareçam inexistentes nas situações observadas nos templos. Você diz que minha visão é restrita, mas perceba quão mais fácil seria se apelássemos para a fé e quantos esforços pouparia se nos resignássemos com a justificativa de que a crença em Deus, por si 
só, reforça comportamentos! Posso, no entanto, dizer-lhe que, da mesma forma que o 'rezar' foi aprendido, a fé em Deus, que você utiliza para explicá-lo, também foi aprendida, o que somente acrescenta, em nosso rol de comportamentos, mais um que foi aprendido (Sidman, 1989) e que também merece as devidas explicações acerca de suas origens. Mas limitemo-nos, primeiramente, ao comportamento de rezar. Eu havia dito que, de alguma maneira, tal comportamento foi seguido por reforçadores que conseguiram a façanha de manter tal hábito presente por muitos anos na vida desses fiéis fervorosos. Provavelmente, se o comportamento de rezar, quando emitido pela primeira vez, fosse apenas seguido de um reforço verbal como um elogio ou qualquer outro sinal de aprovação, o 'rezar' não se sustentaria por muitos anos, mesmo que a conseqüência desse reforçamento tivesse sido a repetição do 'rezar'. O que está implicado aqui não é a legitimidade do reforçamento, mas sua consistência, então deve haver algo além dos reforçadores sociais que garanta a repetição do 'rezar' por muitos anos, mesmo que tais reforçamentos estejam ausentes. E nossa resposta pode estar nas instituições religiosas. Estas não se limitam à modelagem por contingências, mas utilizam regras para garantir que certos comportamentos sejam repetidos ao longo dos anos pelos fiéis que as freqüentam e para evitar que comportamentos inadequados sejam adquiridos. Portanto, nem só de promessas vivem as Igrejas, mas também de ameaças e, em conseqüência, do medo dos fiéis, que os impele ao cumprimento das regras. O medo dos fiéis poderia assim ser traduzido: 'se eu fizer algo que a Igreja me impede de fazer, um terrível infortúnio me sucederá; então, é mais vantajoso que eu antes não o faça, - prefiro obedecê-la'.

Gotтlieb: Mas será a Igreja realmente dessa forma como você descreve, sempre coercitiva em sua essência? Ora, parece-me um costume idiossincrático de vocês, céticos, a manutenção de uma visão unilateral da Igreja! Como se, diante de uma belíssima iconostase de Hagia Sophia, vocês fixassem seus olhares em um pequeno ícone cuja pintura remetesse às chamas infernais, como se filtrassem, ante às incontáveis experiências de beleza e regozijo que um fiel experimenta em seu caminho de devoção, apenas o sofrimento provocado pela punição ao pecado e pela rigidez das regras e do autocontrole.

Tommaso: Não posso deixar de notar o tipo de controle exercido pelas Igrejas. É um controle que envolve punição e reforçamento negativo com muito mais freqüência que o reforçamento positivo; portanto, são agências nas quais a coerção predomina. Era de se esperar, contudo, que as religiões organizadas não se fizessem valer de coerção, pois todas se designam fomentadoras da bondade e do amor, mas o que vemos, na prática, é a utilização das mais variadas regras restritivas e de ameaças de perpetuação do sofrimento após a morte, entre outras formas de coerção (Sidman, 1989).

Gottlieb: Percebo, em seu discurso, uma generalização, de forma que todo aquele possuidor da fé e que reza está necessariamente vinculado a uma instituição religiosa. Existem, entretanto, aqueles que se dizem 'espiritualizados'. De fato, apesar de não aprová-los, percebo que mantêm alguma relação com Deus e que se habituam a orar; de vez em quando, mesmo os infiéis e hipócritas rendem-se ao agradecimento aos Céus pelo ganho de qualquer sorte de coisas mundanas. Como explicar tais ações, que não são subjugadas por leis religiosas?

Tommaso: Perceba que, se listássemos todos os comportamentos relacionados especificamente com a religiosidade, obteríamos um sem-número de ações chamadas 'simbólicas' e comportamentos verbais, e todos eles - repetir textos sagrados, 
juntar as palmas das mãos, erguendo-as próximas ao rosto e ornamentar-se de cruzes e outros artefatos - não são necessariamente aprendidos em uma instituição religiosa. Como todos esses simples comportamentos, a crença em Deus também não é necessariamente governada por leis e aprendida em instituições, mas é obrigatoriamente modelada por contingências. A diferença reside na eficácia das leis, que, aliás, foi rapidamente percebida pelas Igrejas: para que o número de fiéis não diminuísse à medida que os sacrifícios exigidos aumentavam em número e em dificuldade, as Igrejas adotaram leis que traziam conseqüências penosas aos desobedientes. O prazer imediato proporcionado pela quebra de um dos mandamentos não compensava conseqüências tão terríveis. Entretanto, há pessoas que se dizem crentes em Deus, mas que não estão vinculadas a alguma instituição religiosa e não vivem sob a ameaça direta das leis religiosas, embora estejam constantemente observando outras pessoas emitirem comportamentos supersticiosos, ou ainda que aprenderam, no ambiente familiar, apenas alguns resquícios das leis religiosas mais rigorosas e limitam-se ao cumprimento desses resquícios, tendo sido reforçados em seguida por seus familiares, e punidos quando os desobedeceram. Então, é possível perceber que há o controle das Igrejas, ainda que de forma sutil e indireta, nesses sujeitos que você chama de 'espiritualizados'.

Gottlieb: Você é um verdadeiro realista, Tommaso; como um incrédulo, prefere antes duvidar de seus sentidos a admitir um milagre dos Céus ${ }^{1}$. Não esperaria de você atitude diferente em relação a outros fenômenos menos espetaculares, como simples atos de fé de religiosos. Mas sua tentativa de conceber a religião a partir de uma análise comportamental não retira a legitimidade e muito menos os significados que existem contíguos às práticas religiosas.

Tommaso: Não sei se me consideraria um realista. Se eu presenciasse um fato extraordinário, fosse ele considerado produto de 'uma criação subjetiva ou de uma realidade independente do sujeito' (Dittrich, 2005, p. $22)$, não me preocuparia em descobrir se tal fato é ou não verdadeiro, apenas teria a certeza de que eu teria de compreender esse milagre a partir de leis científicas. Assim, provavelmente, eu não me dedicaria em confirmar a verossimilhança do fato, nem me contentaria com as primeiras afirmações de crentes extasiados a respeito das possíveis causas desse milagre. Antes faria uma descrição das contingências de reforço envolvidas e tentaria entender o que está por trás dessas superficiais relações causais. Atenhamo-nos, portanto, ao que você se referiu como sendo as qualidades das práticas religiosas. Primeiramente, você fala que as práticas religiosas têm uma legitimidade. Devo concordar que, de fato, elas possuem sua autenticidade, isto é, as pessoas genuinamente as praticam. Agora, se você usa a palavra 'legitimidade' com o sentido de conformidade às leis, você não poderia ter se servido de palavra melhor! As religiões organizadas regulamentaram o que outrora se tratava de contingências, criando seus próprios códigos penais: condicionaram estímulos aversivos comuns, como as conseqüências de beber e comer em demasia, e qualificaram os comportamentos que os produzem de pecados (Skinner, 1971/1974), equivalentes a crimes hediondos, que não podem ser cometidos sem que haja uma conseqüência em seguida, uma punição severa. Também condicionaram estímulos neutros, o que gerou uma profusão de regras religiosas que não têm sua origem em contingências naturais, como é o caso do quarto mandamento divino, que exige a reserva de um dia da semana para ser santificado e que não era uma regra essencial para a preservação dos membros dos grupos que viviam ainda sem o rigor das leis religiosas. Posteriormente, você fala em 'significados', ou seja, você me diz que uma análise comportamental não retira aquilo que a prática religiosa quer dizer. Mas o que ela quer dizer?
1 Alusão à descrição feita por Dostoiévski, em Os irmãos Karamazov, do personagem Aliócha, cuja característica atribuida pelo autor é a de ser um realista e que, como tal, admite o milagre somente após ter adquirido a fé. 
Quer dizer um sentimento religioso que age ali? Se minha tradução estiver correta, posso, então, concordar com você que o sentimento religioso pode existir dos mais complicados aos mais simples atos de fé, mas nem por isso esse sentimento explica, isoladamente, a gênese de tais atos. Assim como as pessoas não nasceram com uma aptidão para atender a conselhos ou com a virtude da obediência, não é inata a subserviência ao mandamento de amor a Deus (Skinner, 1974). Aliás, se assim fosse, qual seria a precisão desse mandamento? A denominação 'atos de fé' já pressupõe que são atos causados pela fé e, portanto, tal designação não deixa de ser equivocada, pois são, na realidade, atos controlados por regras religiosas inflexíveis. Acho que posso retornar à explicação, portanto, do sentimento de fé, sobre o qual eu havia deixado para falar posteriormente. A fé é um termo utilizado para relatar um sentimento e, como tal, pode ser explicado pelas leis do comportamento, sendo não a causa, mas um produto da relação de controle estabelecida entre homem e ambiente, a saber, na nossa discussão, entre o homem e as agências de controle religiosas. Portanto, não precisamos considerar a fé um evento mental ou inato (Carvalho, 1999). As Igrejas se utilizam, por exemplo, de espetáculos religiosos que suscitam respostas emocionais e que mais tarde serão usados por elas como forma de controle (Skinner, 1953/1981). Então, quando um fiel diz que 'vai à igreja porque tem fé', ele estaria mais correto se dissesse que 'tem fé porque vai à igreja'. Da mesma forma, quando alguém diz: 'ele perdeu a fé', estamos diante de uma situação em que o recém-incrédulo não recebeu mais reforços e, portanto, o comportamento religioso se extinguiu. É o que acontece quando alguém troca de religião ou desiste definitivamente de praticar uma.

GotTlieb: É equivocada a consideração de que todos compreendem suas práticas religiosas da mesma maneira. Há aqueles que se dizem fiéis e freqüentam as igrejas com regularidade, mas preferem as orações repetitivas ao verdadeiro espírito de oração incessante, que é o desejo de estar a serviço de Deus em todos os afazeres do dia a dia, e prestam-se a solenidades sem, no entanto, terem a mínima noção de seu sentido (Kant, 1793/1992). Isso porque esses homens, nos quais imperam quaisquer sentimentos que não a fé, repetem o seu erro de confundir os mandamentos divinos com a legislação do Estado, se proíbem o que a lei diz ser proibido e fazem-no, muitas vezes, para serem reconhecidos pelas comunidades religiosas às quais pertencem como devotos irrepreensíveis. Posso dizer, com certo grau de certeza, que essas atitudes tão pouco religiosas não são raras em minha igreja. E, em relação a elas, devo admitir que seu raciocínio sobre a fé merece algum crédito.

Tommaso: Agradeço o crédito concedido ao meu raciocínio, muito embora eu acredite que minha análise poderia ser estendida a todos aqueles que se dizem religiosos. Para os analistas do comportamento, não é tão difícil entender o porquê da confusão desses homens em relação às leis do Estado e da Igreja. O controle religioso é exercido por regras, e, de forma semelhante, o Estado controla seus cidadãos, ou seja, ambas as agências de controle requerem o cumprimento de leis que freqüentemente traduzem contingências nãocodificadas, e a desobediência a elas acarreta punição. Mas você me chama a atenção para uma situação especial, pois o comportamento governado por leis tende a ser muito pouco reconhecido, visto que a evitação da punição é o verdadeiro imperativo categórico por trás do semblante de obediência virtuosa. Talvez a resposta esteja no fato de que, como uma lei é, com freqüência, a codificação de certas contingências ocorridas em um tempo preexistente ao código, uma pessoa pode submeter-se ao controle direto dessas contingências que originaram a lei, quando é reconhecido socialmente (Skinner, 1974). Assim, membros da Igreja cumprem os 
mandamentos divinos que outrora foram contingências para o bom convívio em coletividade e para a sobrevivência do grupo e, com o cumprimento, são reforçados socialmente. Perceba, entretanto, que sou muito pouco otimista em relação aos outros membros que você acredita serem verdadeiramente religiosos, pois, nesses, eu também veria motivações ligadas à evitação da punição e aos reforçamentos positivo e negativo.

Gottlieb: Mas como alguém pode se portar diante dos mandamentos divinos do mesmo jeito que se portaria diante das leis de um código penal qualquer? As leis governamentais são fruto de mentes humanas, e não possuem outros intentos a não ser a garantia da manutenção de certa ordem coletiva. Já os Santos Mandamentos, através da intervenção de Deus, foram entregues aos homens quando os mandamentos de sua consciência não eram fortes o suficiente para fazê-los resistir ao pecado e fazer valer sua salvação. As Leis divinas requerem muito mais que a ordem coletiva, exigem do indivíduo maior renúncia e a asseveração do amor a Deus e do amor ao próximo (Karenin, 1957).

TOMmAso: Em parte, você está certo, pois devo reconhecer algumas diferenças entre o controle pelas regras religiosas e pelas regras estatais. A obediência às leis religiosas, como você disse, é sobremaneira difícil; os mandamentos divinos são, em sua maioria, descumpridos por um grande contingente de pessoas todos os dias, pois incluem uma série de regulamentos que vão além da proibição dos atos; assim, 'não cobiçarás a mulher do teu próximo' encontra um equivalente muito mais fácil de ser cumprido no código penal, visto que este não proíbe os pensamentos com a mulher do teu próximo. Os mandamentos divinos provêem, inclusive, maior abertura para o reforçamento automático, quando a 'consciência autopunitiva' substitui um controle externo permanente (Skinner, 1953/
1981), sendo que tanto maior é o autocontrole quanto maior for a ênfase dada pela religião à punição e ao auto-reforço, quando o sujeito se sente muito bem e se vangloria por não estar ferindo os códigos, mesmo que não seja reconhecido diretamente por sua comunidade. A maioria das regras religiosas também estão mais propensas a serem reforçadas positivamente quando são cumpridas: é muito mais difícil alguém ser reforçado positivamente por não assediar sexualmente alguém ou por não roubar do que por se abster de relações sexuais ou por jejuar, sendo, com muito mais freqüência, elogiados e reconhecidos os fiéis que se submetem a essas últimas regras.

Gottlieb: Mas e as noções de bem e de mal presentes em todos nós quando ainda éramos crianças? É muito claro, para mim, que tais noções são universais e inerentes ao ser humano! Portanto, a única explicação plausível para esses valores é que há verdadeiramente uma ordem moral no mundo cuja natureza não pode ser outra que não a divina, e que não é apenas fruto de obediência por medo de punição ou para a obtenção de reforços.

Tommaso: Nossos valores não nasceram conosco, mas foram aprendidos quando ainda éramos crianças. Alguns comportamentos nossos eram punidos, então, somente quando nos foi apresentado um estímulo aversivo é que pudemos distinguir o 'certo' do 'errado', através daqueles que eram punidos ou reforçados. Foi assim que surgiu nossa consciência moral e a distinção entre o que é bom e o que é mau. Se não tivéssemos experimentado sensações desprazerosas, esses valores nunca viriam se tornar tão claramente distintos para nós (Sidman, 1989). As crianças sequer conhecem o sentido do altruísmo, e muito menos os adultos conseguem praticálo. A regra de ouro das religiões de fazer aos outros o que quer que façam a você pôde ser reformulada através da análise comportamental, e assumiu um sentido que retira seu estatuto de virtude e lhe atribui um
Mas como alguém pode se portar diante dos mandamentos divinos do mesmo jeito que se portaria diante das leis de um código penal qualquer?

Gottlieb 
Mas o homem

religioso não

estabelece com

Deus uma relação

apoiada em um

dos seus cinco

sentidos. outro mais condizente com a realidade. Assim, fazer aos outros o que quer que façam a você 'significa que você reforça o comportamento dos outros e eles reforçam o seu' (Baum, 1999, p. 227). Se você age egoisticamente com o outro, o outro muito provavelmente responderá agindo também egoisticamente com você, então, por isso, o respeito universal à regra, o que é muito diferente de termos um padrão axiológico de origem mental ou divina.

GotTlieb: Acho que preciso aqui ressaltar uma entre tantas outras diferenças entre a sua ciência e a fé religiosa: 'A ciência estuda tudo que podemos ver e compreender. A fé ocupa-se com aquilo que não podemos ver e raramente conseguimos compreender' (Karenin, 1957, p.3). Eu acredito que Skinner esquece um detalhe primordial no que se refere à religiosidade, que é o fato de que, diferentemente de um animal que vê o dono, o homem não vê Deus (Vergote, 1999). Um cachorro pode aprender a ter medo de seu dono a partir de condicionamento, mas, para que o experimento dê certo, o homem precisa ser visto pelo cachorro, da mesma forma que, para que qualquer aprendizagem tenha sucesso, pelo menos uma experiência sensorial do aprendiz é necessária. Mas o homem religioso não estabelece com Deus uma relação apoiada em um dos seus cinco sentidos. Deus não é sensorial, ele é unicamente percebido e aceito pelo homem através de sua fé. Veja, Tommaso, que sua visão empírica explica somente uma ínfima parte das motivações que fazem com que o homem se torne religioso. Perceba que minha visão é tão radical quanto a sua, entretanto meu pensamento é exatamente o seu virado do avesso: para mim, o homem nasce religioso e pode aprender, ao longo de sua vida, a se tornar um descrente em Deus.

Tommaso: Quão interessante é essa teoria de desaprendizagem religiosa; admite-se que a religião é inata e teremos dado fim a nossa discussão! A explicação pela fé, entretanto, soa como as tentativas de se explicar um comportamento por fatores mentais como ansiedade ou vontade, razões quase tão débeis quanto a fé. Mas a explicação pela fé ainda tem o agravante de se situar em um mundo não só extra-sensorial, mas também para além do racional. Felizmente, o método científico da análise do comportamento, que se dedica estritamente ao conhecimento das leis que regem os comportamentos, impediu que as equívocas relações causais baseadas em fatores internos obscuros retardassem ainda mais os estudos sobre o homem e, inclusive, sobre a sua ligação com a religião.

Gottlieb: É lamentável que o método experimental venha a ser tão restritivo! $\mathrm{O}$ observador fica preso a um único objeto de estudo, e todas as inferências científicas com base nesse método se restringem ao que foi visto ou provado pelo experimentalismo (Bono, 1971). Mas Deus é um Ser que não pode ser isolado para ser observado e quantificado, porquanto Ele não é um ser finito e limitado (Malebranche, 1708/1990). Compreendo, no entanto, que haja uma tendência dos homens de se inclinarem para o empirismo e de confiarem no testemunho de seus sentidos (Malebranche, 1688/1997), pois nós, homens, somos todos finitos, e a infinitude de Deus nos é incompreensível. A religião tem sido mais sábia: tem-se utilizado da fé nas suas inferências, que não é um elemento de pouco alcance. Quando o filho de Deus surgiu, os homens de sua época utilizaram seus sentidos e puderam vê-Lo e ouvi-Lo, mas eles só se tornaram crentes verdadeiramente quando se utilizaram da fé (Albuquerque, 1981). Os religiosos continuam anuindo à verdade da existência de Cristo porque percebem que seus sentidos são insuficientes, obscurecem suas idéias (Malebranche, 1688/1997) e distraem suas mentes das verdades religiosas.

Tommaso: Acho válido você apresentar suas críticas ao método experimental, embora não 
sejam elas novidades para mim. Mesmo pessoas não-religiosas e/ou leigas em análise do comportamento estão propensas a considerar que os experimentos de laboratório se restringem ao conhecimento de certas interações entre organismo e ambiente muito pouco complexas se comparadas às intricadas interações entre organismo e ambiente além dos limites do laboratório, e não podem revelar mais do que o senso comum já reconhece como sendo as causas de seus comportamentos (Benvenuti, 2001). Contudo, a análise do comportamento transcende o conhecimento do senso comum, e não se limita à confirmação ou refutação de tudo aquilo que foi testemunhado pelos sentidos. Quanto à infinitude de Deus, fico devendo uma resposta mais elaborada, mas, no momento, posso lhe dizer que não é de meu interesse, sendo eu um analista do comportamento, comprovar a Sua existência ou a Sua topografia; antes, e talvez devido à minha pobre e limitada condição humana, contento-me em compreender o porquê de os organismos animais e humanos agirem da forma que agem. Mas insisto que certos esclarecimentos que a análise do comportamento tem proporcionado podem nos ajudar a entender assuntos, mesmo os mais controversos como a religião, ao investigar a história de vida do sujeito religioso e ao compreender quais fatores controlam seus comportamentos e como ele interage com o ambiente; assim, inferimos que a religião é apenas mais um agente controlador desse sujeito e que este, por sua vez, tem, na religião, mais um campo de ação.

Gottlıeb: Vejo que, para você, a religião é apenas uma utilidade, um instrumento a mais do qual alguns homens se servem para controlar e punir os demais. Mas como entender as celebrações em que são inegáveis a entrega e o gozo, sem que haja necessariamente promessas receosas de castigos ou pedidos interesseiros? Você não consegue perceber a alegria festiva irrefutavelmente presente nesses momentos de elo afetivo entre o homem e o divino com seu fim nela mesma, e não em interesses imediatos de proteção ou amparo?

Tommaso: Quando você diz 'com seu fim nela mesma', você me diz: o homem se alegra porque está nas celebrações religiosas e está nessas celebrações porque ele se alegra tampouco nos ajuda a compreender os aspectos ligados às celebrações religiosas apelarmos para a fé quanto apelarmos para a alegria festiva. A alegria está relacionada a eventos externos passados ou atuais na história do sujeito e a uma reação fisiológica que acompanha tais eventos; portanto, a alegria não é, em si, o fator causal, mas faz parte de uma cadeia causal, constituída pelo comportamento, pela emoção e pelo evento externo, que não podem ser entendidos separadamente. Junto com uma celebração que foi reforçada e que trouxe conseqüências consideradas agradáveis, o sujeito pode dizer que está alegre por agir de forma benéfica, celebrando a Deus. O interesse imediato de proteção ou amparo não é a forma correta de se explicar o porquê do elo afetivo; precisamos entender não só o que está por trás desse aparente elo afetivo, como também o que está por trás do interesse por esse elo. Quando o sujeito diz se interessar, tal comportamento pode ser traduzido pela linguagem comportamental: o sujeito procura se comportar de forma que se apresentem a ele estímulos chamados 'agradáveis' - que são a conseqüência de determinada resposta -, ou ainda de forma que um estímulo aversivo seja removido. Os reforçamentos positivos e negativos não precisam acontecer imediatamente, como vimos. A Igreja também guarda um poderoso reforçador a longo prazo, que é a alegria ou o alívio eternos no Paraíso, um lugar além desse mundo que reforçará o sujeito por toda a eternidade, mas obviamente a eficácia desse reforçador depende da eficiência do condicionamento verbal da promessa do Paraíso (Skinner, 1953/1981). Já 
vimos que, no entanto, tal promessa isolada é insuficiente para manter tantos fiéis ligados à Igreja, pois estes requerem também reforçadores imediatos. Os reforços positivos imediatos são, por exemplo, elogios e reconhecimento por parte de parentes, conhecidos e líderes religiosos pelo fato de esses fiéis terem se engajado em comportamentos considerados louváveis. O fato de o sujeito dizer que mantém um elo afetivo com Deus é traduzido como uma relação mediada por um comportamento verbal controlado. $\mathrm{O}$ sujeito percebe que o amor que diz sentir por Deus é reforçado positivamente pela comunidade verbal, e isso explica a afirmação do sujeito de que possui um elo afetivo e aparentemente desinteressado.

Gotтlıв: Quando se reduz tudo a uma relação de interesses, corre-se o risco de se esquecer o que a religião pode fazer pelo homem. Se você não considera críveis a salvação e a possibilidade da existência da vida eterna, então que, pelo menos, reconheça que a religião se justifica por proporcionar ao homem a expiação de seus pecados e a aquisição do gosto pela virtude.

TOMmaso: Não sei porque você separou suas justificativas como se as últimas que você apresenta fossem mais críveis para mim. A expiação dos pecados não é menos irracional que a existência de uma vida eterna. Não me contento com justificativas como essas, pois acho que as religiões devem possuir justificativas suficientemente fortes para o tamanho do empreendimento a que elas se propõem, ou seja, para o poderoso controle exercido sobre um contingente infindável de pessoas. Talvez todas elas tenham se fundamentado na preservação da vida humana, entretanto, distorceram o intento original e voltaram-se muito mais para a mera preservação de suas instituições (Skinner, 1987). Assim, se antes a religião trazia uma justificativa fundada para sua existência, podemos hoje considerar que suas práticas punitivas não mais se sustentam; além de serem antiquadas e terem sido consideradas ineficazes pelos estudos promovidos pela análise do comportamento, deixaram de ter fundamentos, à medida que não têm, como seu desígnio principal, a garantia de um futuro promissor para a espécie humana.

Gottlieb: Você está certo quando aponta o fato de que muitas instituições religiosas preocuparam-se, ao longo dos anos, muito mais em defender sua existência do que em ajudar a humanidade. Mas ainda é muito claro para mim que o homem precisa crer no que vai além, que supera o cotidiano simples, que o conforte e dê a ele uma expectativa. Não é por acaso que o homem ainda deseja ter uma religião nos dias de hoje, mesmo após muitas instituições interesseiras terem sido desmascaradas.

TOMmaso: Por mais que eu reconheça que o homem contemporâneo continua sendo controlado por leis fundamentadas em explicações sobrenaturais, não posso me conformar com a idéia de que, para ele, a religião é imprescindível. É curioso vislumbrar uma sociedade que dispensou a religião, quando agências de controle se tornaram irrelevantes. Refiro-me à obra de Skinner em que ele descreve uma sociedade experimental idealizada pelo controverso Frazier ${ }^{2}$, que conseguiu suprir, senão todas, a maioria das necessidades de seus habitantes. Ora, sabemos que nossa sociedade real muito pouco atenua nossos temores ou realiza nossas esperanças, e, quando o faz, raramente deixa de exigir de nós uma prévia disposição para nos engajarmos nas mais variadas atividades desprazerosas: se, por exemplo, desejamos que, em nossa velhice, possamos desfrutar de certa estabilidade financeira, desde cedo devemos pagar uma quantia considerável de dinheiro ao governo e, de tempos em tempos, enfrentar suas imposições burocráticas; por sua vez, para obtermos o dinheiro que pagamos 
ao governo de forma que este nos assegure o futuro, somos obrigados a trabalhar por muitas horas em ofícios monótonos durante um longo número de anos de nossas vidas. Entretanto, mesmo que cumpramos nossas obrigações para com a sociedade, nem sempre podemos ter garantias de que nossos anseios serão devidamente satisfeitos. Nas sociedades Walden, os habitantes não precisam de promessas divinas para alimentar esperanças, uma vez que estão livres das atribulações com as quais nossa sociedade real nos acomete. Diante de uma sociedade livre de sofrimentos, de temores e de insegurança, as práticas religiosas perdem seu sentido. Mas eu não precisaria ter me servido de uma sociedade fictícia ou mesmo das teorias de Skinner para perceber o quão evidente é o fato de que, para um homem que nunca aprendeu a ser religioso e que nunca temeu qualquer desventura em sua vida, a religião é totalmente descartável. Eu o desafio a, da próxima vez que você for assistir à Divina Liturgia, interromper, por alguns segundos, sua bela cantoria bizantina, olhar ao seu redor e reconhecer um devoto em sua igreja que tenha adotado práticas religiosas sem que as tivesse aprendido ainda no seio familiar ou reconhecer outros adeptos que não tenham procurado a igreja quando passavam por momentos de grandes dificuldades.

Gottlıeb: De fato, eu conheço poucas pessoas de minha igreja que não nasceram em um ambiente religioso, mas não acredito que a aprendizagem seja suficiente para que o sujeito se torne verdadeiramente devoto. Há os ensinamentos, sem dúvida, mas estes não são suficientes para garantir uma vida fundada na fé. Quanto ao fato de que haja adeptos que procuraram a igreja apenas no dia em que se viram acometidos por dificuldades, digoIhe que todo aquele que vive sem Deus pode se considerar infeliz e temeroso, esteja ele em evidentes dificuldades ou em uma aparente maré de sorte. Tive a oportunidade, ao longo de minha vida, de conversar com pessoas que resolveram aderir ao cristianismo. Muitas delas me relataram as mudanças que haviam acontecido em suas vidas, e uma dentre elas era o fato de que, em suas famílias, as discórdias tinham quase que totalmente cessado desde que passaram a se portar segundo os ensinamentos de Cristo. Também me parece um fenômeno muito comum entre novos e antigos adeptos uma profunda mudança de caráter proporcionada pela religião. Aquele que busca uma religião, portanto, para nós, não será mais que um simples aprendiz de lições religiosas ou um azarado às voltas com seu desespero, mas um espírito inquieto que sente agora o genuíno desejo de voltar sua alma para o Divino?

Tommaso: A respeito dos convertidos, Gottlieb, acredito que haja, principalmente, o reforçamento negativo envolvido na conversão. A adesão à religião pode acontecer por diferentes situações, mas penso que há a implicação da possibilidade de retirada de um estímulo aversivo operando na vida da maioria dos novos adeptos. Trata-se de um comportamento supersticioso, pois essas pessoas acreditam que haja uma relação causal entre a conversão religiosa e a retirada de um estímulo aversivo. Quanto às mudanças operadas em suas vidas, há a possibilidade de incidência de comportamentos supersticiosos, pois é plausível que haja uma coincidência entre um comportamento emitido (a conversão) e o reforço (a diminuição de discórdias). O mesmo processo atua quando se acusa o outro de ter feito algo errado, que supostamente ocasionou determinada desventura, devendo esta ser encarada como um aviso para que novas atitudes erradas não sejam repetidas. Essa forma de contingência, através do reforçamento acidental, é, aliás, a forma de controle, senão a mais utilizada, a mais característica das instituições religiosas (Skinner, 1957/1981): os fiéis acreditam, por exemplo, que, se não cumprirem as leis das Igrejas, serão punidos de alguma forma em seu dia a dia e/ou com o fogo do inferno (Banaco, 1996). As pessoas, no entanto, 
também seguem regras quando estas podem trazer conseqüências que lhe são agradáveis (Skinner, 1974). Assim, a discórdia pode ter diminuído pelas regras religiosas que aconselham a tolerância ao próximo, e o afastamento das brigas é um reforçador negativo para o cumprimento das regras, então, talvez aqui possamos inferir que não é de todo supersticiosa a relação adesão-alívio. Há também, nas igrejas, aquilo que nós chamamos de aprendizagem vicária: as igrejas possuem uma infinidade dos chamados 'exemplos de vida', pessoas santificadas que emitiram comportamentos considerados muito bons, como proclamar o amor a Deus e distribuir todos os seus pertences para os pobres, assim, os fiéis tentam imitar tais comportamentos exemplares. É verdade que dificilmente alguém consegue adquirir todos esses comportamentos quase sobre-humanos; as hagiografias estão comumente repletas de todos os tipos de privações e superações de punições positivas, assim a Igreja pode justificar a santificação desses homens e a contemplação dirigida a eles. Esses exemplos de homens extraordinários, como o próprio Cristo, são elevados a um patamar de adoração e admiração. Dessa forma, esperase que o fiel queira, para si, a glorificação e o prestígio que esses homens conseguiram tão somente após a morte, já que a vida deles nos é, de fato, muito pouco atrativa. Obviamente, a Igreja precisa contar com outras formas de modificação de comportamentos, pois o prestígio post mortem dificilmente dá razão suficiente a uma vida tão árdua.

Gottlieb: Então como entender o persistente número elevado de adeptos das Igrejas? Se você não considera que é pelo fato de que a religião seja fundamental ao homem, não é curioso que o grau de adesão se mantenha elevado, enquanto o grau de coerção da Igreja se tenha modificado, ao longo da História?

TOMmaso: Permita-me dispor minhas respostas em ordem inversa às suas perguntas, pois seu último questionamento chamou-me a atenção por já ter incluído não só a resposta a ele mesmo, mas também a todos os seus questionamentos anteriores. Você não somente chamou a atenção para um fato histórico como anunciou uma pré-condição para que tal fenômeno fosse possível: não só o grau de adesão se manteve relativamente elevado bem como o grau de coerção foi modificado, como o número de adeptos só pôde manter-se elevado com a modificação do grau de coerção infligida pela Igreja! Quando as instituições religiosas exercem um controle coercitivo quase ilimitado, os indivíduos por ela controlados podem ser reforçados negativamente, de tal forma que passam a exercer um contracontrole. Isso significa que, a longo prazo, o controle surtiu um efeito negativo e não previsto, pois o contracontrole age, sobretudo, sob a forma do desligamento definitivo da instituição (Skinner, 1974). A Igreja Católica Romana, por exemplo, percebeu esse contracontrole, e o que se vê, hoje em dia, são as tentativas desesperadas para angariar novos fiéis e recuperar os que a abandonaram. A coerção infligida por tantos anos, ao longo de sua história, teve de ser revista, e a Igreja percebeu que perderia cada vez mais fiéis se continuasse adotando uma postura punitiva ao invés de se dedicar mais ao reforçamento do 'comportamento religioso' para evitar a saída de fiéis e a mudança de parte destes para outras religiões concorrentes (Skinner, 1989). Percebeu que um fiel tanto mais permanece 'espontaneamente' ligado a uma Igreja quanto mais reforçadora esta for; a ameaça de punição pelo abandono das práticas religiosas é muito menos eficaz, e os comportamentos ditos religiosos, quando não suficientemente reforçados, tendem a se extinguir, como já a análise experimental do comportamento pôde prever a partir de seus resultados em laboratórios sem que precisasse fazer observações em templos, daí a importância do método experimental. Veja que a previsão de comportamentos é possível a partir da observação de comportamentos operantes e 
do controle de variáveis ainda em espaços muito menos complexos que instituições religiosas.

Gotтlieb: É preciso reconhecer, Tommaso, que a visão religiosa do homem, ao contrário da visão behaviorista radical, é a de um ser que possui um livre-arbítrio. Deus não impede que as pessoas se utilizem de seu discernimento e de sua criatividade, mesmo que poucos sejam os homens que reconheçam toda a sua potência. Um deus que freqüentemente interviesse nas ações humanas e as controlasse faria com que a vida perdesse seu sentido, e ela se tornaria redundante (Albuquerque, 1981), pois que os homens agiriam unicamente segundo a vontade divina rumo a um caminho certo de perfeição, seriam máquinas, e, como tal, desprovidas de espírito. Entretanto, Deus não age através das mãos humanas, porém dá a elas o movimento para agir, e, à cabeça do homem que as possui, o tino necessário para a decisão de suas ações. Se, então, ao homem é permitida a fé e a dúvida, cabe a ele julgar o melhor caminho a seguir, seja ele o tortuoso da danação ou o reto da virtude.

Tommaso: É inegável o fato de que a religião atribui aos seres humanos um poder irreal, torna-os senhores de si. Mas os homens pagam um preço elevado por tal atribuição quando se culpam terrivelmente por todas as decisões que julgam posteriormente terem sido tomadas inadequadamente. É uma postura cômoda da religião, pois a ela cabe o julgamento, e, aos homens, toda a responsabilidade por suas decisões. Skinner chegou a comentar que o Deus cristão não quer, de fato, controlar os seres humanos: a eles permite, senão o livrearbítrio, a capacidade de se autocontrolarem e a de controlarem o ambiente, mantendo com este uma relação recíproca de modelagem (Skinner, 1980). Já pude, aliás, trazer alguns esclarecimentos sobre a origem de certos comportamentos; podemos inferir que nenhum destes surge ao acaso, e o livrearbítrio, portanto, não deixa também de ser uma idéia enganosa, e sustentada pela religião, pois assim pode imbuir seus fiéis de sentimento de culpa e abster-se de responsabilidades e do reconhecimento das verdadeiras origens das atitudes pecaminosas. Se a religião se presta ao serviço de buscar essas origens, ela deverá não apenas buscar, na história desses 'pecadores', as verdadeiras circunstâncias que fizeram essas atitudes serem qualificadas como pecados (Skinner, 1971/1974) mas também rever todas as suas medidas e práticas punitivas, porém creio que, para uma revolução desse porte, a religião se mostrará muito pouco disposta.

Gottlieb: Você fala em uma revolução na religião, mas veja os resultados de todas as revoluções no campo da ciência! A falta de firmeza das convicções científicas é inegável, e vocês, cientistas, dão-se o direito de opinar sobre o campo religioso, o mais perene e fecundo entre todos os outros. Todos os anos, cientistas lançam uma nova 'moda'; alguns criam teorias mirabolantes em um intervalo de tempo tão rápido quanto outros o levam para derrubá-las (Karenin, 1957). Ademais, nenhuma descoberta sobre os fatos mais inexplicáveis e importantes da vida humana foi oferecida pela ciência, e ninguém deveria dar tanto crédito às suas descobertas vacilantes e interinas. E quanto de consolo e felicidade ela pode nos proporcionar (Freud, 1932/1969)? Quem, por sua vez, tem estado ao lado do homem durante todos os anos em que os artefatos científicos sequer haviam saído da imaginação dos primeiros homens que os inventaram? Continuo defendendo a religião como a mais importante das ciências humanas. Antes de nos debruçarmos em explicações científicas acerca do que vem a ser a religião e esperarmos, da ciência, um futuro mais aprazível, deveríamos persistir nos estudos religiosos, pois, conforme minha doutrina ensina, além de minha sabedoria, necessito, antes de tudo, da minha fé. 'As verdades sobre Deus, que é invisível e impossível de descrever, e sua sabedoria estão 
escondidas em grandes mistérios; disso se compreende que uma parte do estudo da religião não pode ser compreendida por meios comuns, mas pode ser sentida unicamente com o auxílio da fé, e assim agimos de forma que as verdades se gravem profundamente nos nossos corações e para que possamos atingir a salvação de nossas almas!' (Karenin, 1957).

TOMmASO: Não posso garantir que uma ciência do comportamento salve as nossas almas, mas posso asseverar que ela permite ao homem o conhecimento de seu potencial, sem que precise apelar para idéias ilusórias de iniciativa e liberdade (Skinner, 1971/1974). O homem é controlado pelo ambiente e, como vimos, também pelos ditames religiosos, que integram seu ambiente social. Portanto, é uma perda de tempo bendizê-lo ou amaldiçoá-lo por todas as suas ações e pensamentos. Não há dúvida de que uma ciência do comportamento venha talvez a desagradar-lhe com certas verdades que ele não está disposto a aceitar, mas elas são fundamentais para que o homem reconheça que o ambiente ao seu redor é também um produto de sua ação. $\mathrm{E}$, apesar de a ciência ter tido sempre a árdua tarefa de desiludir a humanidade (Skinner, 1953/1981), não deixa de ser tal empreendimento infinitamente mais dignificante e libertador que qualquer princípio falso que destitua o homem de seu verdadeiro potencial e que o impeça de construir um futuro pautado em uma tecnologia científica capaz de atenuar seus sofrimentos e de tornálo, assim, mais verdadeiramente digno e senhor de si. 
Tyffanne Serra Paraná Rodrigues Psicóloga pela Universidade Federal do Paraná, Mestranda em Estudos Lingüísticos pela Universidade Federal do Paraná.

Alexandre Dittrich

Psicólogo, Doutor em Filosofia pela Universidade Federal de São Carlos, professor do Departamento de Psicologia da Universidade Federal do Paraná

Praça Santos Andrade, 50 - Prédio Central - 2o andar - Sala 215 - Centro. Curitiba - Paraná - CEP: 80.060-240 - Telefone: (041) 3310-2625 - Fax (041) 3310-2641. E-mail: aledittrich@ufpr.br

ALBUQUERQUE, M. M. O Homem entre a Ciência e a Religião. Curitiba: Beija-Flor, 1981.

BANACO, R. A. O. Manejo de aspectos religiosos na prática clínica comportamental. Psicologia Revista, v. 3, 1996, pp. 103-109.

BAUM, W. M. Compreender o Behaviorismo. Porto Alegre: Artmed, 1999.

BENVENUTI, M. F. Comportamento "Supersticioso": Possíveis Extensões para o Comportamento Humano. In: Guilhardi, H. J.; Madi, M. B. B. P.; Queiroz, P. P.; Scoz, M.C. (org.). Sobre Comportamento e Cognição, Santo André: ESETec, 2001, v. 6, pp. 29-34.

BONO, E. É a Ciência uma Nova Religião? Ou os Perigos do Dogma Científico. Rio de Janeiro: Civilização Brasileira, 1971.

CARVALHO, S. G. O. O lugar dos sentimentos na ciência do comportamento e na psicoterapia comportamental. Psicologia: Teoria e Prática, São Paulo, v. 1, n. 2, pp. 33-36, 1999.

DITTRICH, A. A Atividade Científica como Objeto da Ciência: uma Perspectiva Contextualista Behaviorista Radical. Trabalho apresentado no II Encontro da Rede Paranaense de Pesquisa em História e Filosofia da Ciência, SCHLA/UFPR, Curitiba, 2005.

DOSTOIÉVSKI, F. Os Irmãos Karamazov. São Paulo: Abril Cultural, 1970

FREUD, S. Novas Conferências Introdutórias sobre Psicanálise. Conferência XXV - A Questão de uma Weltanschauung. In: Edição Eletrônica Brasileira das Obras Psicológicas Completas de Sigmund Freud, v.22. Rio de Janeiro: Imago, 1932,1969.

KANT, I. A Religião nos Limites da Simples Razão. Lisboa: Edições 70, 1793-1992.
KARENIN, J. B. Doutrina Cristã Ortodoxa. São Paulo: Santa Igreja Greco-Ortodoxa do Brasil, 1957.

MALEBRANCHE, N. Dialogues on Metaphysics and on Religion. Cambridge: Cambridge University Press, 1997.

MALEBRANCHE, N. Diálogo de um Filósofo Cristão e de um Filósofo Chinês: sobre a Existência e a Natureza de Deus. Lisboa: Edições 70, 1990.

SIDMAN, M. Coerção e suas Implicações. Campinas: Livro Pleno, 1989.

SKINNER, B. F. Ciência e Comportamento Humano. São Paulo: Martins Fontes, 1953,1981.

Walden Dos, Madrid: Fontanella, 1948,1976.

Para além da Liberdade e da Dignidade. Lisboa: Edições 70, 1971,1974.

Sobre o Behaviorismo. São Paulo: Cultrix, 1974.

Notebooks. Englewood Cliffs: Prentice-Hall, 1980. Hall, 1987

Upon further Reflection. Englewood Cliffs: Prentice-

Questões Recentes na Análise Comportamental. Campinas: Papirus, 1989.

VERGOTE, A. Necessidade e Desejo da Religião na Ótica da Psicologia. In: Paiva, G. J. (org.) Entre Necessidade e Desejo. Diálogos da

Psicologia com a Religião. São Paulo: Loyola, 1999, pp. 9-24.

\section{Referências}

